\title{
Rhodococcus koreensis sp. nov., a 2,4-dinitrophenol-degrading bacterium
}

\author{
Jung-Hoon Yoon, ${ }^{1}$ Young-Gyun Cho, ${ }^{2}$ Seok-Sung Kang, ${ }^{1}$ \\ Seung Bum Kim, ${ }^{3}$ Sung Taik Lee ${ }^{2}$ and Yong-Ha Park ${ }^{1}$
}

Author for correspondence: Yong-Ha Park. Tel: +8242860 4620. Fax: +82428604625 e-mail:yhpark@kribb4680.kribb.re.kr

\footnotetext{
${ }^{1}$ Korea Research Institute of Bioscience and Biotechnology (KRIBB), PO Box 115, Yusong, Taejon, Korea

2 Department of Biological Sciences, Korea Advanced Institute of Science and Technology, Taejon, Korea

3 Department of Agricultural and Environmental Science, University of Newcastle, Newcastle upon Tyne NE1 7RU, UK
}

\begin{abstract}
A 2,4-dinitrophenol-degrading bacterial strain, DNP505', which was isolated from an industrial wastewater, was taxonomically studied by a polyphasic approach using phenotypic, chemotaxonomic and genetic methods. Strain DNP505 ${ }^{\top}$ has a cell wall of chemotype IV containing meso-diaminopimelic acid, arabinose and galactose. The predominant menaquinone is $\mathbf{M K}-8\left(\mathrm{H}_{2}\right)$. Mycolic acids contain 43-53 carbon atoms. Strain DNP505 ${ }^{\top}$ has a cellular fatty acid profile containing straight-chain saturated, unsaturated and 10-methylbranched fatty acids and has $\mathrm{C}_{\mathbf{1 6 : 0}}$ as the major fatty acid. The DNA G+C content is $66 \mathrm{~mol} \%$. Strain DNP505 ${ }^{\top}$ formed a coherent cluster with Rhodococcus species in a phylogenetic inference based on 165 rDNA sequences. Interestingly, strain DNP505 ${ }^{\top}$ was found to have two types of 165 rDNA sequence, which showed 10 bp sequence differences $(99 \cdot 3 \%$ nucleotide similarity). Its differences in some phenotypic characteristics and its genetic distinctiveness indicate that strain DNP505 ${ }^{\top}$ is separate from Rhodococcus species described previously. It is therefore proposed that strain DNP505 ${ }^{\top}$ should be placed in the genus Rhodococcus as a new species, Rhodococcus koreensis. The type strain of the new species is strain DNP505 ${ }^{\top}$ ( = KCTC 0569BP' $=$ JCM 10743').
\end{abstract}

Keywords: Rhodococcus koreensis sp. nov., 2,4-dinitrophenol degradation, polyphasic taxonomy

\section{INTRODUCTION}

Nitroaromatic compounds are frequently used as building blocks for dyes, plastics, explosives, herbicides and pesticides, and are also important as solvents (Lenke et al., 1992; Marvin-Sikkema \& de Bont, 1994). However, despite their industrial importance, nitroaromatic compounds are in most cases highly toxic to living organisms, including microorganisms. They are abundantly present in nature and, in particular, are found as contaminants in waste waters, rivers and herbicide- or pesticide-treated soils (Lenke et al., 1992; Marvin-Sikkema \& de Bont, 1994). In spite of the toxicity of nitroaromatic compounds, several micro-organisms that are able to convert or degrade nitroaromatic compounds have been found to exist in nature (Marvin-Sikkema \& de Bont, 1994). Such microbes have been used for degrading many nitroaromatic compounds or cleaning of nitro-

The GenBank accession numbers for the two types of $16 \mathrm{~S}$ rDNA sequence of strain DNP505 ${ }^{\top}$ are AF124342 and AF124343, respectively. aromatic-contaminated sites (Bruhn et al., 1987; Cho et al., 1998; Zeyer \& Kearney, 1984).

2,4-Dinitrophenol is a well known toxic aromatic compound. It causes toxicity by uncoupling oxidative phosphorylation in the mitochondria of cells (Ilvicky \& Casida, 1969; Simon, 1953). It causes 'dinitrophenol poisoning' to man exposed to contaminated environments (Leftwich et al., 1982). The classic syndrome of 'dinitrophenol poisoning' includes lassitude, malaise, headache, increased perspiration, thirst, profound weight loss and respiratory failure (Leftwich et al., 1982). Some bacterial strains have been reported to degrade 2,4-dinitrophenol (Hess et al., 1990; Lenke et al., 1992). Such useful strains utilizing 2,4-dinitrophenol as sole carbon and nitrogen sources have been isolated in our laboratory. Among them, one strain (DNP505) was found to have high ability to utilize or degrade 2,4-dinitrophenol and was considered to be a member of the genus Rhodococcus. The aim of this study was to determine the exact phylogenetic position of strain DNP505. We describe its morphological and 
physiological characteristics, its phylogeny based on 16S rDNA sequences and its DNA relatedness with some Rhodococcus species and other mycolic-acidcontaining taxa. On the basis of this data, we propose a new species of the genus Rhodococcus, Rhodococcus koreensis, for strain DNP505 ${ }^{\mathrm{T}}$.

\section{METHODS}

Bacterial strains. Strain DNP505 $5^{\mathrm{T}}$ was isolated by selective enrichment from an industrial wastewater in Cheong-Ju, Korea. The wastewater samples were inoculated in $50 \mathrm{ml}$ minimal salts medium (Yoon et al., 1997) containing (per litre) $1 \mathrm{~g} \mathrm{~K}_{2} \mathrm{HPO}_{4}, 0.5 \mathrm{~g} \mathrm{NaH}_{2} \mathrm{PO}_{4} .2 \mathrm{H}_{2} \mathrm{O}, 0.25 \mathrm{~g} \mathrm{KCl}, 0.25 \mathrm{~g}$ $\mathrm{MgSO}_{4} \cdot 7 \mathrm{H}_{2} \mathrm{O}, 1 \mathrm{ml}$ trace element solution (Lee et al., 1991) supplemented with $100 \mathrm{mg} \mathrm{2,4-dinitrophenol} \mathrm{l}^{-1}$ and $15 \mathrm{~g}$ agar (if needed). This medium was incubated at $30^{\circ} \mathrm{C}$ on a horizontal shaker at 150 r.p.m. When the yellow colour of the medium had disappeared, $5 \mathrm{ml}$ of the suspension was transferred into $50 \mathrm{ml}$ fresh medium. To isolate pure cultures, the suspension was plated on solid media containing 2,4-dinitrophenol. Single colonies were tested to investigate their ability to utilize 2,4-dinitrophenol as sole carbon and energy sources for growth. One strain (DNP505) was selected for further studies. Rhodococcus species used as reference organisms were obtained from DSMZ (Deutsche Sammlung von Mikroorganismen und Zellkulturen) and KCTC (Korean Collection for Type Cultures).

Culture conditions. For investigation of morphological and physiological characteristics, strain DNP505 $5^{\mathrm{T}}$ was cultivated on trypticase soy agar (TSA; BBL) at $28^{\circ} \mathrm{C}$. Cell mass for analyses of cell wall, mycolic acids and menaquinones was obtained from trypticase soy broth (BBL) cultures. Cell mass for DNA extraction was produced in trypticase soy broth supplemented with glucose $(0.75 \%$, w/v). Strain DNP505 5 was cultivated at $28^{\circ} \mathrm{C}$ on a horizontal shaker at 150 r.p.m. The broth cultures were checked for purity before they were harvested by centrifugation. For fatty acid methyl ester (FAME) analysis, cell mass of strain DNP505 ${ }^{\mathrm{T}}$ and Rhodococcus species was obtained from agar plates after growing for $6 \mathrm{~d}$ on TSA.

Morphological and physiological characterization. The morphology of cells was examined by light microscopy, and scanning- and transmission electron microscopy. For scanning electron microscopy, cells from early-growth phase and stationary phase were prepared by the method described by Bozzola \& Russell (1991) and the specimens were examined with a model 535M scanning electron microscope (Philips). For transmission electron microscopy, cells from the stationary phase were negatively stained with $1 \%(\mathrm{w} / \mathrm{v})$ phosphotungstic acid, and after air-drying the grids were examined by using a model CM-20 transmission electron microscope (Philips). Motility was determined with an optical microscope using the hanging-drop technique (Skerman, 1967). Catalase activity was determined by bubble formation in a $3 \%$ hydrogen peroxide solution. Oxidase activity was determined by oxidation of $1 \% p$ aminodimethylaniline oxalate. Hydrolysis of casein and of starch, and production of urease were determined as described by Cowan \& Steel (1965). Hydrolysis of aesculin and of arbutin were determined according to the method of Kurup \& Fink (1975). Hydrolysis of elastin was determined according to the method of Williams et al. (1983). Tests for utilization of various substrates as sole carbon and energy sources were performed as described by Shirling \& Gottlieb (1966). Most of the substrates were tested at a concentration of $1 \%(\mathrm{w} / \mathrm{v})$; the exception was glycerol $(0 \cdot 1 \%, \mathrm{w} / \mathrm{v})$. The utilization results were checked over a period of 4 weeks.

Isolation of DNA. Chromosomal DNA was isolated and purified according to the method described previously (Yoon et al., 1996), with the exception that ribonuclease T1 was used together with ribonuclease A.

Chemotaxonomic characterization. The isomer of diaminopimelic acid in the peptidoglycan was determined by the method described by Komagata \& Suzuki (1987). The sugar composition of the cell wall was determined by the method described by Saddler et al. (1991). The acyl type of the peptidoglycan was determined by the method of Uchida \& Aida (1977). Menaquinones were analysed as described by Komagata \& Suzuki (1987) using reversed-phase HPLC. Mycolic acids were extracted and purified as their methyl esters according to the procedures described by Minnikin (1988). The numbers of carbon atoms in the mycolic acids were calculated from the mass spectra of the methyl esters taken from an Autospec M mass spectrometer (Micromass) operated in electron impact mode. Fatty acids were extracted and analysed according to the instructions of the Microbial Identification System (MIDI).

Determination of $\mathbf{G}+\mathbf{C}$ content. The $\mathrm{G}+\mathrm{C}$ content was determined by the method of Tamaoka \& Komagata (1984). DNA was hydrolysed and the resultant nucleotides were analysed by reversed-phase HPLC.

DNA-DNA hybridization. Rhodococcus erythropolis KCTC $1062^{\mathrm{T}}$, Rhodococcus fascians DSM 20669 ${ }^{\mathrm{T}}$, Rhodococcus globerulus DSM 43954 ${ }^{\mathrm{T}}$, Rhodococcus marinonascens DSM $43752^{\mathrm{T}}$, Rhodococcus opacus DSM $43205^{\mathrm{T}}$ and Rhodococcus percolatus DSM $44240^{\mathrm{T}}$ were used as reference strains for DNA-DNA hybridization. DNA-DNA hybridization was performed fluorometrically in microdilution wells according to the procedures described by Ezaki et al. (1989).

$16 \mathrm{~S}$ rDNA sequencing. The $16 \mathrm{~S}$ rDNA of strain DNP505 was amplified by PCR using two universal primers as described previously (Yoon et al., 1998). The PCR amplification of the $16 \mathrm{~S}$ rDNA of strain DNP505 ${ }^{\mathrm{T}}$ was also performed at different annealing temperatures and various concentrations of DNP mix and primers. Cloning of $16 \mathrm{~S}$ rDNA was carried out by using the method described previously (Kim et al., 1995). Sequencing of 16S rDNA and the cloned $16 \mathrm{~S}$ rDNA was performed as described previously (Yoon et al., 1998).

Phylogenetic analysis. The $16 \mathrm{~S}$ rDNA sequence of strain DNP505 ${ }^{\mathrm{T}}$ was aligned with 16S rRNA gene sequences of Rhodococcus species and some other related actinomycete taxa by using CLUSTAL W software (Thompson et al., 1994). $16 \mathrm{~S}$ rDNA similarity values were calculated from the alignment. Gaps at the 5' and $3^{\prime}$ ends of the alignment were omitted from further analyses. Evolutionary distance matrices were calculated by using the algorithm of Jukes \& Cantor (1969) with the DNADIST program within the PHYLIP package (Felsenstein, 1993). A phylogenetic tree was constructed by using the neighbour-joining method (Saitou \& Nei, 1987) as implemented within the NEIGHBOR program of the same package. The stability of relationships was assessed by a bootstrap analysis of 1000 data sets by using the programs SEQBOOT, DNADIST, NEIGHBOR and CONSENSE of the PHYLIP package.

Nucleotide sequence accession numbers. GenBank and EMBL accession numbers for reference 16S rDNA sequences used in this analysis are as follows: X80626 (Rhodococcus coprophilus DSM $43347^{\mathrm{T}}$ ), X79289 (Rhodococcus erythropolis DSM 43066 ${ }^{\mathrm{T}}$ ), X80614 (Rhodococcus 
equi DSM 20307T), X79186 (Rhodococcus fascians DSM $20669^{\mathrm{T}}$ ), X80619 (Rhodococcus globerulus DSM 43954 ${ }^{\mathrm{T}}$ ), X80617 (Rhodococcus marinonascens DSM 43752 ${ }^{\mathrm{T}}$ ), X80630 (Rhodococcus opacus DSM 43205'), X92114 [Rhodococcus percolatus strain MBS1 $^{\mathrm{T}}$ (Briglia et al., 1996)], X80621 (Rhodococcus rhodnii DSM 43336 ${ }^{\mathrm{T}}$ ), X79288 (Rhodococcus
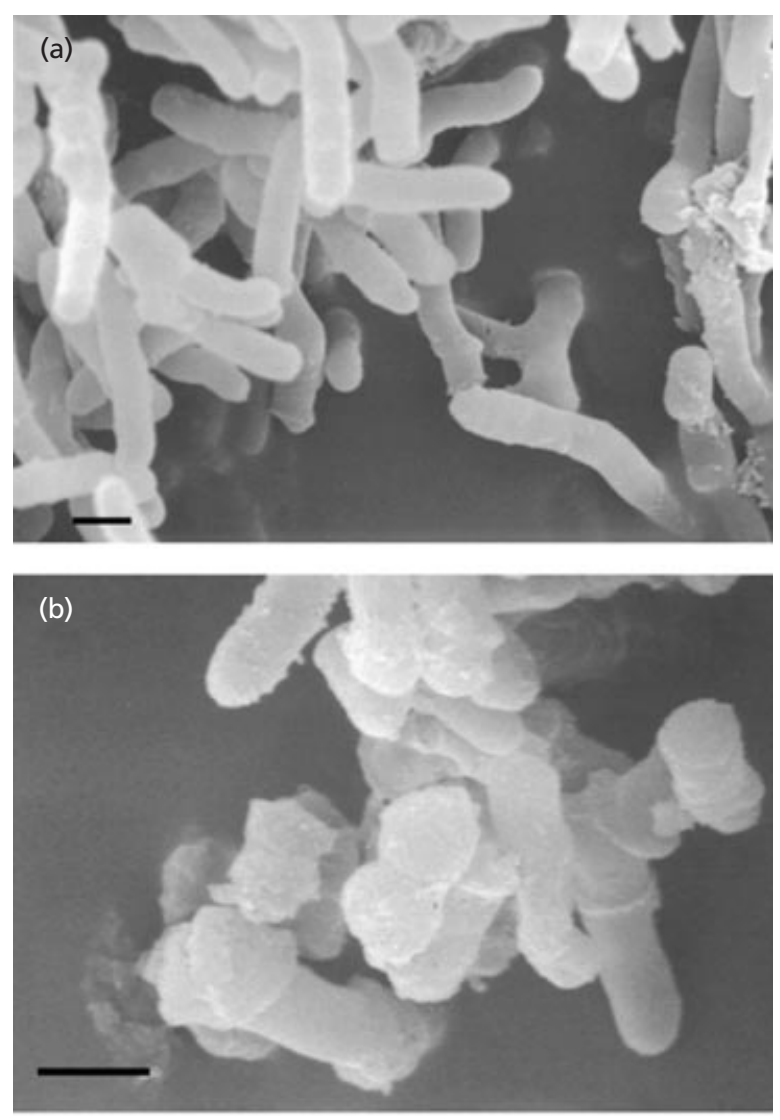

(c)

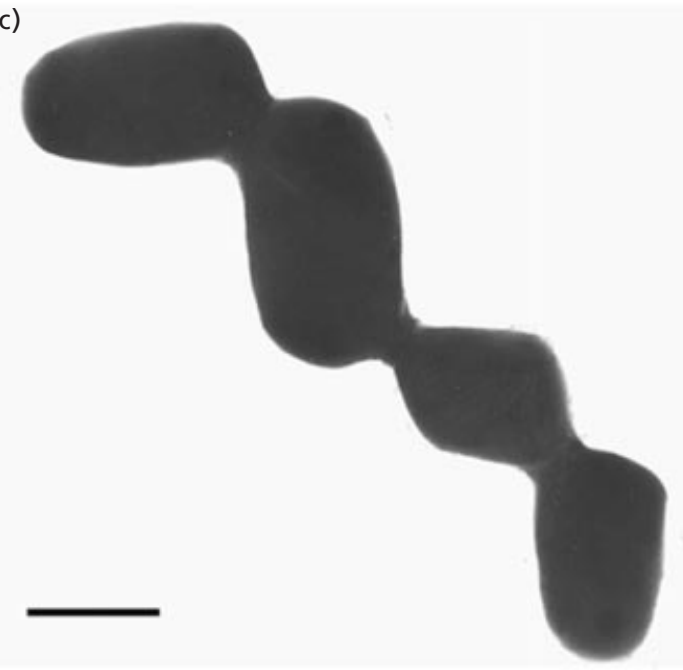

Fig. 1. Scanning- and transmission electron microscopy of strain DNP $505^{\top}$ grown on TSA. (a, b) Scanning electron micrographs of strain DNP505 ${ }^{\top}$ at early-growth phase (a) and at exponentialgrowth phase (b). (c) Transmission electron micrograph of strain DNP505 $5^{\top}$ at exponential-growth phase. Bars, $1 \mu \mathrm{m}$. rhodochrous DSM 43241 ${ }^{\mathrm{T}}$ ), X80625 (Rhodococcus ruber DSM 43338 ${ }^{\mathrm{T}}$ ), X81934 (Rhodococcus zopfii ATCC 51349 ${ }^{\mathrm{T}}$ ), X84248 (Corynebacterium diphtheriae NCTC 11397T), X79290 (Dietzia maris DSM $43672^{\mathrm{T}}$ ), X79287 (Gordonia bronchialis DSM 43247 ), X80632 (Gordonia rubripertincta DSM 43197 ${ }^{\mathrm{T}}$ ), X52917 [Mycobacterium tuberculosis (Rogall et al., 1990)], X80606 (Nocardia asteroides DSM 43757 $)$, X80608 (Nocardia brasiliensis DSM 43758 ${ }^{\mathrm{T}}$ ), X80611 (Nocardia otitidiscaviarum DSM 43242 ${ }^{\mathrm{T}}$ ), Z35435 (Skermania piniformis IFO $15059^{\mathrm{T}}$ ) and X80628 (Tsukamurella paurometabola DSM 20162 ${ }^{\mathrm{T}}$ ).

\section{RESULTS}

\section{Morphological and physiological characteristics}

Strain DNP505 ${ }^{\mathrm{T}}$ is an aerobic, non-motile and Grampositive bacterium. A substrate mycelium that penetrates into agar media is observed which often fragments into rod to coccus elements. Cells are rods, form filaments or show elementary branching at early-

Table 1. Physiological characteristics of some Rhodococcus species and strain DNP505

All results are from this study. + , Positive reaction; - , negative reaction; w, weakly positive reaction. All strains were positive for catalase, hydrolysis of Tween 80 and urea; and utilization of D-ribose, D-fructose, D-glucose, D-mannose, sucrose, D-trehalose, D-mannitol, D-sorbitol and glycerol as sole carbon and energy sources. All strains were negative for oxidase; hydrolysis of casein, elastin and starch; and utilization of D-cellobiose, adonitol, dulcitol and sodium benzoate as sole carbon and energy sources. Species: 1,

$R$. erythropolis KCTC $1062^{\mathrm{T}} ; 2$, R. fascians DSM 20669 $; 3$, R. globerulus DSM 43954 $;$ 4, R. opacus DSM 43205 ${ }^{\mathrm{T}} ; 5$, $R$. percolatus DSM $44240^{\mathrm{T}} ; 6$, strain DNP505 ${ }^{\mathrm{T}}$.

\begin{tabular}{|c|c|c|c|c|c|c|}
\hline Character & 1 & 2 & 3 & 4 & 5 & 6 \\
\hline \multicolumn{7}{|l|}{ Hydrolysis of: } \\
\hline Arbutin & + & - & + & - & - & - \\
\hline Aesculin & + & - & + & - & - & - \\
\hline \multicolumn{7}{|c|}{ Utilization of as sole carbon and energy sources: } \\
\hline L-Arabinose & - & + & - & - & - & $\mathrm{w}$ \\
\hline D-Xylose & - & + & + & $\mathrm{w}$ & + & + \\
\hline D-Galactose & - & $\mathrm{w}$ & - & + & + & + \\
\hline L-Rhamnose & - & - & - & - & - & + \\
\hline Lactose & - & - & - & + & + & + \\
\hline Maltose & - & - & - & + & + & + \\
\hline Melezitose & - & - & - & + & + & + \\
\hline D-Melibiose & - & - & - & + & + & + \\
\hline D-Raffinose & - & - & - & + & + & + \\
\hline D-Turanose & - & - & - & + & + & + \\
\hline Arabitol & - & + & + & + & + & + \\
\hline myo-Inositol & + & - & - & + & + & + \\
\hline Xylitol & - & + & + & + & + & + \\
\hline Inulin & + & $\mathrm{w}$ & + & + & + & + \\
\hline Sodium acetate & + & - & + & + & + & + \\
\hline Trisodium citrate & + & - & + & + & + & + \\
\hline Disodium succinate & + & - & + & + & + & + \\
\hline 2,4-Dinitrophenol & - & - & - & - & + & + \\
\hline
\end{tabular}


Table 2. Cellular fatty acid profiles of some Rhodococcus species and strain DNP505

Species: 1, R. coprophilus DSM 43347" ; 2, R. equi KCTC 9082 ${ }^{\mathrm{T}} ; 3$, R. erythropolis KCTC $1062^{\mathrm{T}}$; 4, $R$. fascians DSM 20669 $; 5, R$. globerulus DSM 43954 $;$ T, $R$. opacus DSM $43205^{\mathrm{T}} ; 7, R$. percolatus DSM $44240^{\mathrm{T}} ; 8, R$. rhodnii DSM 43336 ${ }^{\mathrm{T}}$; 9 , $R$. rhodochrous $\mathrm{KCTC} 9086^{\mathrm{T}} ; 10$, R. ruber DSM $43338^{\mathrm{T}}$; 11, R. zopfii DSM 44108 ${ }^{\mathrm{T}}$; 12 , strain DNP505 ${ }^{\mathrm{T}}$.

\begin{tabular}{|c|c|c|c|c|c|c|c|c|c|c|c|c|}
\hline Fatty acid & 1 & 2 & 3 & 4 & 5 & 6 & 7 & 8 & 9 & 10 & 11 & 12 \\
\hline \multicolumn{13}{|l|}{ Saturated } \\
\hline $\mathrm{C}_{13: 0}$ & & & & & & $0 \cdot 6$ & & & & & & \\
\hline $\mathrm{C}_{14: 0}$ & $1 \cdot 8$ & $2 \cdot 9$ & $7 \cdot 3$ & $4 \cdot 6$ & $2 \cdot 3$ & $3 \cdot 0$ & $3 \cdot 4$ & $3 \cdot 1$ & $1 \cdot 7$ & $1 \cdot 5$ & $1 \cdot 7$ & $2 \cdot 8$ \\
\hline $\mathrm{C}_{15: 0}^{10.0}$ & $2 \cdot 7$ & $1 \cdot 3$ & $5 \cdot 0$ & $5 \cdot 2$ & $1 \cdot 6$ & $15 \cdot 6$ & $10 \cdot 7$ & $3 \cdot 3$ & 1.9 & $2 \cdot 9$ & $1 \cdot 0$ & $11 \cdot 6$ \\
\hline $\mathrm{C}_{16: 0}^{10.0}$ & $23 \cdot 1$ & $26 \cdot 1$ & $22 \cdot 0$ & $26 \cdot 4$ & $27 \cdot 4$ & $24 \cdot 6$ & $28 \cdot 6$ & $34 \cdot 3$ & $22 \cdot 7$ & $27 \cdot 4$ & $32 \cdot 7$ & $28 \cdot 4$ \\
\hline $\mathrm{C}_{17: 0}$ & $1 \cdot 8$ & $17 \cdot 3$ & & $1 \cdot 7$ & $2 \cdot 7$ & $7 \cdot 5$ & $6 \cdot 6$ & $1 \cdot 4$ & $2 \cdot 8$ & $4 \cdot 3$ & & $11 \cdot 4$ \\
\hline $\mathrm{C}_{18: 0}$ & & $2 \cdot 4$ & & $1 \cdot 4$ & $4 \cdot 0$ & $1 \cdot 3$ & 1.9 & $1 \cdot 0$ & 1.9 & $2 \cdot 4$ & $8 \cdot 8$ & $2 \cdot 7$ \\
\hline $\mathrm{C}_{19: 0}$ & & $3 \cdot 4$ & $10 \cdot 9$ & & $13 \cdot 0$ & & & & $2 \cdot 7$ & & 0.6 & $0 \cdot 5$ \\
\hline $\mathrm{C}_{20: 0}$ & & & $5 \cdot 1$ & & $2 \cdot 6$ & & & & $5 \cdot 2$ & & $2 \cdot 1$ & \\
\hline \multicolumn{13}{|l|}{ Unsaturated } \\
\hline $\mathrm{C}_{15: 1}$ cis 10 & & & & & & $0 \cdot 8$ & $0 \cdot 5$ & & & & & \\
\hline$C_{15: 1}^{10.1} B^{*}$ & & & & & & $0 \cdot 7$ & $0 \cdot 6$ & & & & & 0.5 \\
\hline $\mathrm{C}_{16: 1}^{10.1}$ cis 9 & $5 \cdot 6$ & $1 \cdot 5$ & $2 \cdot 8$ & $0 \cdot 9$ & & $6 \cdot 9$ & $9 \cdot 0$ & & $4 \cdot 1$ & $1 \cdot 2$ & $6 \cdot 6$ & $7 \cdot 0$ \\
\hline $\mathrm{C}_{16: 1} \mathrm{~B}^{*}$ & & & & & $2 \cdot 1$ & & & & $1 \cdot 0$ & & & \\
\hline $\mathrm{C}_{17: 1}$ cis 9 & $1 \cdot 3$ & & $3 \cdot 0$ & $3 \cdot 1$ & $1 \cdot 0$ & $17 \cdot 8$ & $14 \cdot 2$ & $2 \cdot 3$ & $1 \cdot 6$ & $4 \cdot 3$ & $1 \cdot 2$ & $16 \cdot 7$ \\
\hline $\mathrm{C}_{17: 1}$ cis 10 & & $4 \cdot 4$ & & & & & & & & & & \\
\hline $\mathrm{C}_{18: 1}$ cis 9 & $2 \cdot 4$ & $3 \cdot 2$ & $9 \cdot 7$ & $26 \cdot 2$ & $15 \cdot 5$ & $9 \cdot 5$ & $11 \cdot 3$ & $13 \cdot 7$ & $6 \cdot 0$ & $20 \cdot 7$ & $16 \cdot 5$ & $10 \cdot 6$ \\
\hline $\mathrm{C}_{20: 4}$ cis $5,8,11,14$ & & & & & & & & & $2 \cdot 4$ & & & \\
\hline $\mathrm{C}_{20: 1}$ cis 11 & & & & & & & & & $0 \cdot 6$ & & $1 \cdot 7$ & \\
\hline \multicolumn{13}{|l|}{ Cyclo } \\
\hline $\mathrm{C}_{17: 0}$ & $1 \cdot 8$ & & & & & & & & & & & \\
\hline \multicolumn{13}{|l|}{ 10-Methyl } \\
\hline $\mathrm{C}_{16: 0}$ & $12 \cdot 5$ & $2 \cdot 7$ & $2 \cdot 1$ & & & $0 \cdot 5$ & $0 \cdot 7$ & & $5 \cdot 2$ & $0 \cdot 6$ & $2 \cdot 9$ & \\
\hline $\mathrm{C}_{17: 0}$ & $4 \cdot 5$ & $1 \cdot 6$ & $2 \cdot 4$ & $1 \cdot 3$ & $0 \cdot 9$ & $2 \cdot 8$ & $2 \cdot 3$ & $2 \cdot 1$ & $2 \cdot 2$ & $1 \cdot 8$ & & $1 \cdot 5$ \\
\hline $\mathrm{C}_{18: 0}$ & $24 \cdot 1$ & $18 \cdot 2$ & $11 \cdot 0$ & $11 \cdot 5$ & $14 \cdot 3$ & $1 \cdot 8$ & $2 \cdot 4$ & $23 \cdot 7$ & $22 \cdot 8$ & $15 \cdot 6$ & $13 \cdot 1$ & $1 \cdot 3$ \\
\hline \multicolumn{13}{|l|}{ Summed features $\dagger$} \\
\hline Summed feature 4 & $16 \cdot 1$ & $8 \cdot 2$ & $16 \cdot 6$ & $14 \cdot 1$ & 10 & $5 \cdot 2$ & $4 \cdot 7$ & $15 \cdot 2$ & $14 \cdot 3$ & $15 \cdot 9$ & $9 \cdot 4$ & $2 \cdot 6$ \\
\hline Summed feature 6 & & & & $0 \cdot 9$ & & & & & & & & \\
\hline Summed feature 7 & & $1 \cdot 3$ & & & & & & & & & $1 \cdot 3$ & \\
\hline Summed feature 8 & & & $2 \cdot 1$ & $2 \cdot 9$ & $1 \cdot 2$ & $1 \cdot 1$ & $1 \cdot 2$ & & $0 \cdot 9$ & $1 \cdot 3$ & & $1 \cdot 1$ \\
\hline Summed feature 9 & & $3 \cdot 7$ & & & & & & & & & & \\
\hline Unknown fatty acid & $2 \cdot 4$ & $2 \cdot 0$ & & & $1 \cdot 5$ & & & & & & & \\
\hline
\end{tabular}

* The double-bond position indicated by a capital letter is unknown.

$\dagger$ Summed features represent groups of two or three fatty acids which could not be separated by GLC with the MIDI system. Summed features 4, 6, 7, 8 and 9 contained one or more of the following fatty acids: summed feature 4, 15:0 iso 2-OH and/or 16:1 $\operatorname{trans} 9$; summed feature 6, 18:0 anteiso and/or 18:2 cis 9,12; summed feature 7, 18:1 cis 11, 18:1 trans 6 and/or 18:1 trans 9; summed feature 8, unknown 18.756 and/or 19:1 cis 10 ; summed feature 9, unknown $18 \cdot 846$, unknown 18.858 and/or 19:0 cyclo.

growth phase and fragment into short rods or cocci during exponential-growth phase (Fig. 1). Most cells in stationary phase are cocci. Colonies are creamcoloured, opaque and convex with slightly irregular edges on TSA. Strain DNP505 ${ }^{\mathrm{T}}$ showed catalase and urease activities but no oxidase activity. It grew optimally over a broad $\mathrm{pH}$ range of $6 \cdot 0-8 \cdot 0$, and growth was slow or inhibited at $\mathrm{pH}$ values below $5 \cdot 0$ and above $10 \cdot 0$. It grew optimally at temperatures of
25-30 ${ }^{\circ} \mathrm{C}$. Some other physiological properties of strain DNP505 ${ }^{\mathrm{T}}$ are shown in Table 1, together with those of some Rhodococcus species.

\section{Chemotaxonomic characteristics and DNA base composition}

The cell wall of strain DNP505 ${ }^{\mathrm{T}}$ contained mesodiaminopimelic acid as the diamino acid, and ar- 


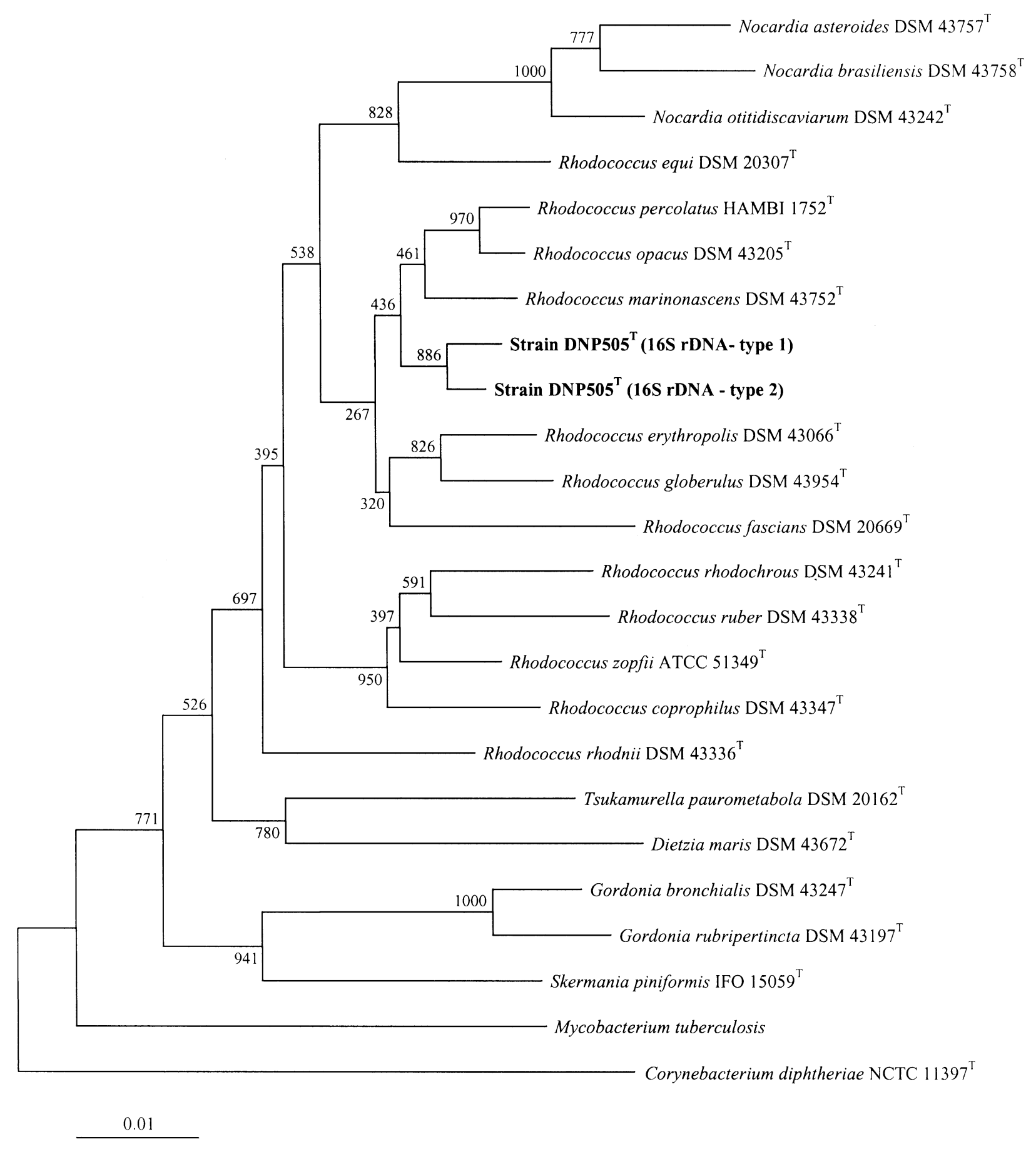

Fig. 2. Phylogenetic tree based on $16 \mathrm{~S}$ rDNA sequences showing the positions of strain $\mathrm{DNP} 505^{\top}$, Rhodococcus species and representatives of other mycolic-acid-containing actinomycete taxa. Scale-bar represents 0.01 substitution per nucleotide position. Bootstrap values are shown at the branch points.

abinose and galactose as major cell wall sugars, indicating wall chemotype IV (Lechevalier \& Lechevalier, 1970). The acyl type in the muramic acid of the peptidoglycan was glycolyl. The major isoprenoid quinone was dihydrogenated menaquinone with eight isoprenoid units $\left[\mathrm{MK}-8\left(\mathrm{H}_{2}\right)\right]$. Strain DNP505 ${ }^{\mathrm{T}}$ contained major amounts of mycolic acids with 43-53 carbon atoms. It had a cellular fatty acid profile containing straight-chain saturated, unsaturated and 10-methyl-branched fatty acids, and had $\mathrm{C}_{16: 0}$ as the major fatty acid and relatively high proportions of $\mathrm{C}_{15: 0}, \mathrm{C}_{17: 0}, \mathrm{C}_{17: 1}$ (cis 9) and $\mathrm{C}_{18: 1}$ (cis 9) (Table 2). Branched saturated and hydroxy fatty acids were not detected (Table 2). 
The genomic DNA G + C content of strain DNP505 ${ }^{\mathrm{T}}$ was $66 \mathrm{~mol} \%$, a value within the range known in the genus Rhodococcus (Takeuchi \& Hatano, 1998).

\section{S rDNA sequence analysis}

An almost complete nucleotide sequence of the $16 \mathrm{~S}$ rDNA was determined by directly sequencing single strands of $16 \mathrm{~S}$ rDNAs obtained by treatment with $\lambda$ exonuclease following PCR amplification. Interestingly, strain DNP505 ${ }^{\mathrm{T}}$ was found to have two types of 16S rDNA sequence, which showed $10 \mathrm{bp}$ sequence differences $(99 \cdot 3 \%$ nucleotide similarity). These differences were found in the region corresponding to that between positions 508 and 631 of the $16 \mathrm{~S}$ rDNA of Escherichia coli. This observation has three possible explanations: contamination with other organisms, PCR amplification error and heterogeneity in the $16 \mathrm{~S}$ rDNA sequences within strain DNP505 ${ }^{\mathrm{T}}$. The possibility of contamination was eliminated because an identical result was obtained from new cultures that had been checked and confirmed to be uncontaminated. The possibility of PCR amplification error was also eliminated because identical results were obtained when repeated PCR, PCR under different conditions and PCR with an enzyme having $3^{\prime}$ to $5^{\prime}$ exonuclease proofreading activity were performed. Accordingly, it was concluded that strain DNP505 ${ }^{\mathrm{T}}$ shows heterogeneity in $16 \mathrm{~S}$ rDNA sequences between rRNA gene clusters. When the region showing sequence differences from several (10) clones containing $16 \mathrm{~S}$ rDNA was sequenced, two types of sequence were found. However, the number and heterogeneity of rRNA gene clusters of strain DNP505 ${ }^{\mathrm{T}}$ were not investigated in $r r n$ loci distinguished by the use of restriction endonucleases. The two types of $16 \mathrm{~S}$ rDNA sequence were simply designated type 1 and type 2 .

The two types of $16 \mathrm{~S}$ rDNA sequence determined were $1473 \mathrm{bp}$ long, and corresponded to the region between positions 28 and 1524 of the 16S rDNA of E. coli. The $16 \mathrm{~S}$ rDNA sequences of strain DNP505 ${ }^{\mathrm{T}}$ were compared with those of Rhodococcus species and representatives of other mycolic-acid-containing taxa. The phylogenetic tree (Fig. 2) shows that strain DNP505 occupies a distinct lineage within the cluster enclosed by the genus Rhodococcus and forms a coherent cluster with $R$. opacus, $R$. percolatus, $R$. marinonascens, $R$. fascians, $R$. globerulus and $R$. erythropolis. Strain DNP $505^{\mathrm{T}}$ exhibited levels of $16 \mathrm{~S}$ rDNA similarity of 95.6-98.8\% with type strains of validly described Rhodococcus species. It was interesting that one type (type 1) of $16 \mathrm{~S}$ rDNA sequence of strain DNP505 exhibited highest similarity to $R$. opacus at $98.8 \%$ whereas the other type (type 2) exhibited highest similarity to $R$. percolatus at $98 \cdot 6 \%$.

\section{DNA-DNA relatedness test}

DNA-DNA relatedness tests were performed between strain DNP505 ${ }^{\mathrm{T}}$ and the type strains of some Rhodococcus species with which it formed a coherent cluster according to phylogenetic analysis based on 16S rDNA sequences. Strain DNP505 $5^{\mathrm{T}}$ exhibited levels of DNA-DNA relatedness of 29, 30, 19, 32, 27 and 35\% to $R$. opacus, $R$. percolatus, $R$. marinonascens, $R$. fascians, $R$. globerulus and $R$. erythropolis, respectively.

\section{DISCUSSION}

The genus Rhodococcus is an industrially important taxon which includes many strains used for amino acid production, transformation of steroids, etc. The genus Rhodococcus is also a very significant taxon from the point of view of bioremediation. Many Rhodococcus strains have been described as degrading toxic aromatic compounds such as chlorinated phenols (Briglia et al., 1996), dinitrophenol (Lenke et al., 1992) and naphthalene (Grund et al., 1992). However, mycolicacid-containing taxa, including the genus Rhodococcus, had been taxonomically confused because of similar morphological and chemotaxonomic properties (Goodfellow, 1992). Recently, reliable classification of mycolic-acid-containing taxa has been achieved by integrating 16S rDNA sequences and chemotaxonomic properties (Chun et al., 1997; Rainey et al., 1995a, b; Takeuchi \& Hatano, 1998). Many species belonging to this group have been transferred to other genera or reclassified as new genera by integration of phylogenetic analyses based on $16 \mathrm{~S}$ rDNA sequences and chemotaxonomic analyses (Chun et al., 1997; Klatte et al., 1994; Rainey et al., 1995b). Mycolic-acid-containing genera are currently classified into six families within the suborder Corynebacterineae and the genus Rhodococcus is included in the family Nocardiaceae together with the genus Nocardia (Stackebrandt et al., 1997). The genus Rhodococcus can be taxonomically distinguished from other mycolic-acid-containing actinomycete genera by a combination of chemotaxonomic and phylogenetic data.

Chemotaxonomic properties and phylogenetic inference based on 16S rDNA sequences indicate clearly that strain DNP505 ${ }^{\mathrm{T}}$ belongs to the genus Rhodococcus. The predominant menaquinone type of strain

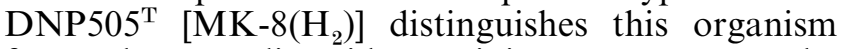
from other mycolic-acid-containing genera, except the genus Dietzia containing $\mathrm{MK}-8\left(\mathrm{H}_{2}\right)$ and the genus Corynebacterium containing MK-8 $\left(\mathrm{H}_{2}\right)$ or MK- $9\left(\mathrm{H}_{2}\right)$ (Takeuchi \& Hatano, 1998). The genera Gordonia and Mycobacterium have MK-9 $\left(\mathrm{H}_{2}\right)$, the genera Nocardia and Skermania have MK- $8\left(\mathrm{H}_{4}, \omega\right.$-cycl $)$ and the genus Tsukamurella has MK-9, as predominant menaquinones (Takeuchi \& Hatano, 1998). The acyl type (glycolyl) found in the peptidoglycan of strain DNP505 ${ }^{\mathrm{T}}$ distinguishes this organism from the genera Dietzia and Corynebacterium, whose acyl type is acetyl. The length of carbon chains of the mycolic acids of strain DNP505 ${ }^{\mathrm{T}}$ is different from those of the genera Gordonia, Mycobacterium, Skermania and Tsukamurella (Takeuchi \& Hatano, 1998). The phylogenetic inference based on 16S rDNA sequences is consistent 
with results obtained from chemotaxonomic analyses. Strain DNP505 ${ }^{\mathrm{T}}$ exhibited its highest homology to Rhodococcus species and formed a coherent cluster with $R$. opacus, $R$. percolatus, $R$. marinonascens, $R$. fascians, R. globerulus and R. erythropolis (Fig. 2).

Strain DNP505 $5^{\mathrm{T}}$ was found to be a very interesting organism, showing heterogeneity in its 16S rDNA sequences. This is the first report of a strain showing $16 \mathrm{~S}$ rDNA sequence heterogeneity within the actinomycetes. The existence of heterogeneous 16S rDNA sequences within a single organism has been reported in only a few bacteria. Camphylobacter helveticus (Linton et al., 1994), Clostridium paradoxum (Rainey et al., 1996), Paenibacillus polymyxa (Nübel et al., 1996) and the archaeon Haloarcula marismortui (Mylvaganam \& Dennis, 1992) are known to contain multiple 16S rRNA genes with intervening sequences (IVSs) or sequence heterogeneity between 16S rRNA genes within one organism. Many bacteria are known to contain multiple $r r n$ loci in their genomes (Baylis \& Bibb, 1988; Kim et al., 1993) and most investigations have noted a high degree of sequence identity of $r r n$ genes within one organism. Therefore, heterogeneity of 16S rRNA gene sequences between $r r n$ loci within one organism might be questioned. However, such a possibility might have been overlooked because the method of choice for most 16S rRNA gene sequencing involves the use of $16 \mathrm{~S}$ rDNA amplified by PCR using total genomic DNA without distinction between rRNA operons within an organism (Weisburg et al., 1991). The 16S rRNA heterogeneity shown by strain DNP505 $5^{\mathrm{T}}$ supports the possibility that inter-operon variability within a single strain may exist in more cases than known previously. The existence of heterogeneous 16S rRNA gene sequences may also be considered from the point of view of phylogenetic analysis. Among the two types of 16S rDNA sequence of strain DNP505 ${ }^{\mathrm{T}}$, one type exhibited highest similarity to the $16 \mathrm{~S}$ rDNA of $R$. percolatus whereas the other type exhibited highest similarity to the $16 \mathrm{~S}$ rDNA of $R$. opacus. It is therefore evident that strain DNP505 ${ }^{\mathrm{T}}$ possesses a phylogenetically unique property which is not shown by other Rhodococcus species.

Physiological characteristics of strain DNP505 ${ }^{\mathrm{T}}$ were compared with some Rhodococcus species (type strains of $R$. opacus, $R$. percolatus, $R$. fascians, $R$. globerulus and $R$. erythropolis) that were phylogenetically related based on 16S rDNA sequence analysis. Strain DNP505 5 was similar to R. opacus and R. percolatus in physiological characteristics as shown in cellular fatty acid profiles and phylogenetic inference based on $16 \mathrm{~S}$ rDNA sequences. However, the ability to utilize rhamnose as carbon source was found only in strain DNP505 ${ }^{\mathrm{T}}$ and not in other species, including $R$. opacus and $R$. percolatus. Also, weak utilization of arabinose was shown by strain DNP505 $5^{\mathrm{T}}$ but not by $R$. opacus and $R$. percolatus. The ability to degrade 2,4 -dinitrophenol was shown by both strain DNP505 and $R$. percolatus, but strain DNP505 $5^{\mathrm{T}}$ did not show the ability to degrade 2,4,6-trichlorophenol which is charac- teristic of $R$. percolatus. DNA-DNA relatedness provided important data for determining the taxonomic position of strain DNP505 ${ }^{\mathrm{T}}$ within the genus Rhodococcus. Although not all Rhodococcus species were used in DNA-DNA relatedness tests, those used in this study were considered to be sufficient because they and strain DNP505 ${ }^{\mathrm{T}}$ formed a coherent phylogenetic cluster (Fig. 2). Levels of DNA-DNA relatedness between strain DNP505 ${ }^{\mathrm{T}}$ and the type strains of some Rhodococcus species exhibited values that genetically distinguish strain DNP $505^{\mathrm{T}}$ from other species (Wayne et al., 1987). Its differences in some phenotypic characteristics and its genetic distinctiveness indicate that strain DNP505 ${ }^{\mathrm{T}}$ is separate from Rhodococcus species described previously.

On the basis of data described above, strain DNP505 ${ }^{\mathrm{T}}$ should be placed in the genus Rhodococcus as a new species, for which we propose the name Rhodococcus koreensis sp. nov.

\section{Description of Rhodococcus koreensis sp. nov.}

Rhodococcus koreensis (ko.re.en'sis. M.L. adj. koreensis referring to Korea, the country where strain DNP $505^{\mathrm{T}}$ was isolated and taxonomically studied).

Cells are Gram-positive and non-motile. They are rods, form filaments or show elementary branching at early-growth phase and are mostly cocci in stationary phase. Colonies are cream-coloured, opaque and convex, with slightly irregular edges on TSA. Forms a substrate mycelium that fragments into rod to coccus elements. Grows optimally at $\mathrm{pH} 7 \cdot 0-7 \cdot 8$ and at $25-30{ }^{\circ} \mathrm{C}$. Oxidase-negative and catalase- and ureasepositive. Tween 80 is hydrolysed. Aesculin, arbutin, casein, elastin and starch are not hydrolysed. LArabinose, D-ribose, D-xylose, D-fructose, D-galactose, D-glucose, D-mannose, L-rhamnose, lactose, maltose, melezitose, D-melibiose, sucrose, D-trehalose, Draffinose, turanose, myo-inositol, D-mannitol, Dsorbitol, arabitol, xylitol, inulin, glycerol, sodium acetate, trisodium citrate and disodium succinate are utilized as sole carbon and energy sources. D-Cellobiose, adonitol, dulcitol and sodium benzoate are not utilized. Degrades 2,4-dinitrophenol. The cell wall contains meso-diaminopimelic acid, arabinose and galactose (wall chemotype IV). The predominant menaquinone is $\mathrm{MK}-8\left(\mathrm{H}_{2}\right)$. The major fatty acid is $\mathrm{C}_{16: 0}$. Mycolic acids contain 43-53 carbon atoms. The $\mathrm{G}+\mathrm{C}$ content of the DNA is $66 \mathrm{~mol} \%$ (as determined by HPLC). Isolated from an industrial wastewater in Cheong-ju, Korea. The type strain is strain DNP505 ${ }^{\mathrm{T}}$, which has been deposited in the Korean Collection for Type Cultures as KCTC 0569BP ${ }^{\mathrm{T}}$ and in the Japan Collection of Microorganisms as JCM 10743 ${ }^{\mathrm{T}}$.

\section{ACKNOWLEDGEMENTS}

This work was supported by grants HS2321 and HS2701 from the Ministry of Science and Technology (MOST) of the Republic of Korea. 


\section{REFERENCES}

Baylis, H. A. \& Bibb, M. J. (1988). Organisation of the ribosomal RNA genes in Streptomyces coelicolor A3(2). Mol Gen Genet 211, 191-196.

Bozzola, J. J. \& Russell, L. D. (1991). Electron Microscopy: Principles and Techniques for Biologists. Boston: Jones \& Bartlett Publishers.

Briglia, M., Rainey, F. A., Stackebrandt, E., Schraa, G. \& SalkinojaSalonen, M. S. (1996). Rhodococcus percolatus sp. nov., a bacterium degrading 2,4,6-trichlorophenol. Int J Syst Bacteriol 46, 23-30.

Bruhn, C., Lenke, H. \& Knackmuss, H.-J. (1987). Nitrosubstituted aromatic compounds as nitrogen source for bacteria. Appl Environ Microbiol 53, 208-210.

Cho, Y.-G., Yoon, J.-H., Park, Y.-H. \& Lee, S.-T. (1998). Simultaneous degradation of $p$-nitrophenol and phenol by a newly isolated Nocardioides sp. J Gen Appl Microbiol 44, 303-309.

Chun, J., Blackall, L. L., Kang, S.-O., Hah, Y. C. \& Goodfellow, M. (1997). A proposal to reclassify Nocardia pinensis Blackall et al. as Skermania piniformis gen. nov., comb. nov. Int $J$ Syst Bacteriol 47, 127-131.

Cowan, S. T. \& Steel, K. J. (1965). Manual for the Identification of Medical Bacteria. London: Cambridge University Press.

Ezaki, T., Hashimoto, Y. \& Yabuuchi, E. (1989). Fluorometric deoxyribonucleic acid-deoxyribonucleic acid hybridization in microdilution wells as an alternative to membrane filter hybridization in which radioisotopes are used to determine genetic relatedness among bacterial strains. Int J Syst Bacteriol 39, 224-229.

Felsenstein, J. (1993). PHYLIP: phylogeny inference package, version 3.5. Seattle: University of Washington.

Goodfellow, M. (1992). The family Nocardiaceae. In The Prokaryotes, 2nd edn, pp. 1188-1213. Edited by A. Balows, H. G. Trüper, M. Dworkin, W. Harder \& K.-H. Schleifer. New York: Springer.

Grund, E., Denecke, B. \& Eichenlaub, R. (1992). Naphthalene degradation via salicylate and gentisate by Rhodococcus sp. strain B4. Appl Environ Microbiol 58, 1874-1877.

Hess, T. F., Schmidt, S. K., Silverstein, J. \& Howe, B. (1990). Supplemental substrate enhancement of 2,4-dinitrophenol mineralization by a bacterial consortium. Appl Environ Microbiol 56, 1551-1558.

Ilvicky, J. \& Casida, J. E. (1969). Uncoupling action of 2,4dinitrophenols, 2-trifluoromethylbenzimidazoles and certain other pesticide chemicals upon mitochondria from different sources and its relation to toxicity. Biochem Pharmacol 18, 444- 445 .

Jukes, T. H. \& Cantor, C. R. (1969). Evolution of protein molecules. In Mammalian Protein Metabolism, vol. 3, pp. 21-132. Edited by H. N. Munro. New York: Academic Press.

Kim, E., Kim, H., Hong, S.-P., Kang, K. H., Kho, Y. H. \& Park, Y.-H. (1993). Gene organization and primary structure of a ribosomal RNA gene cluster from Streptomyces griseus subsp. griseus. Gene 132, 21-31.

Kim, S.-B., Yoon, J.-H., Kim, H., Lee, S.T., Park, Y.-H. \& Goodfellow, M. (1995). A phylogenetic analysis of the genus Saccharomonospora conducted with 16S rRNA gene sequences. Int J Syst Bacteriol 45, 351-356.

Klatte, S., Rainey, F. A. \& Kroppenstedt, R. M. (1994). Transfer of Rhodococcus aichiensis Tsukamura 1982 and Nocardia amarae Lechevalier and Lechevalier 1974 to the genus Gordona as
Gordona aichiensis comb. nov. and Gordona amarae comb. nov. Int J Syst Bacteriol 44, 769-773.

Komagata, K. \& Suzuki, K.-I. (1987). Lipids and cell-wall analysis in bacterial systematics. Methods Microbiol 19, 161-203.

Kurup, V. P. \& Fink, J. N. (1975). A scheme for the identification of thermophilic actinomycetes associated with hypersensitivity pneumonitis. J Clin Microbiol 2, 55-61.

Lechevalier, M. P. \& Lechevalier, H. A. (1970). A critical evaluation of the genera of aerobic actinomycetes. In The Actinomycetales, pp. 393-405. Edited by H. Prauser. Jena: Gustav Fischer.

Lee, S. T., Lee, S. B. \& Park, Y. H. (1991). Characterization of a pyridine-degrading branched Gram-positive bacterium isolated from the anoxic zone of an oil shale column. Appl Microbiol Biotechnol 35, 824-829.

Leftwich, R. B., Floro, J. F., Neal, R. A. \& Wood, A. J. (1982). Dinitrophenol poisoning: a diagnosis to consider in undiagnosed fever. South Med J 75, 182-184.

Lenke, H., Pieper, D. H., Bruhn, C. \& Knackmuss, H.-J. (1992). Degradation of 2,4-dinitrophenol by two Rhodococcus erythropolis strains, HL 24-1 and HL 24-2. Appl Environ Microbiol 58, 2928-2932.

Linton, D., Dewhirst, F. E., Clewley, J. P., Owen, R. J., Burnens, A. P. \& Stanley, J. (1994). Two types of $16 \mathrm{~S}$ rRNA gene are found in Campylobacter helveticus: analysis, applications and characterization of the intervening sequence found in some strains. Microbiology 140, 847-855.

Marvin-Sikkema, F. D. \& de Bont, J. A. M. (1994). Degradation of nitroaromatic compounds by microorganisms. Appl Microbiol Biotechnol 42, 499-507.

Minnikin, D. E. (1988). Isolation and purification of mycobacterial wall lipids. In Bacterial Cell Surface Techniques, pp. 125-135. Edited by I. C. Hancock \& I. C. Poxton. Chichester: Wiley.

Mylvaganam, S. \& Dennis, P. P. (1992). Sequence heterogeneity between the two genes encoding $16 \mathrm{~S}$ rRNA from the halophilic archaebacterium Haloarcula marismortui. Genetics 130, 399-410.

Nübel, U., Engelen, B., Felske, A., Snaidr, J., Wieshuber, A., Amann, R. I., Ludwig, W. \& Backhaus, H. (1996). Sequence heterogeneities of genes encoding $16 \mathrm{~S}$ rRNAs in Paenibacillus polymyxa detected by temperature gradient gel electrophoresis. $J$ Bacteriol 178, 5636-5643.

Rainey, F. A., Burghardt, J., Kroppenstedt, R. M., Klatte, S. \& Stackebrandt, E. (1995a). Phylogenetic analysis of the genera Rhodococcus and Nocardia and evidence for the evolutionary origin of the genus Nocardia from within the radiation of Rhodococcus species. Microbiology 141, 523-528.

Rainey, F. A., Klatte, S., Kroppenstedt, R. M. \& Stackebrandt, E. (1995b). Diezia, a new genus including Diezia maris comb. nov., formerly Rhodococcus maris. Int J Syst Bacteriol 45, 32-36.

Rainey, F. A., Ward-Rainey, N. L., Janssen, P. H., Hippe, H. \& Stackebrandt, E. (1996). Clostridium paradoxum DSM $7308^{\mathrm{T}}$ contains multiple 16S rRNA genes with heterogeneous intervening sequences. Microbiology 142, 2087-2095.

Rogall, T., Wolters, J., Flohr, T. \& Böttger, E. C. (1990). Towards a phylogeny and definition of species at the molecular level within the genus Mycobacterium. Int $J$ Syst Bacteriol 40, 323-330.

Saddler, G. S., Tavecchia, P., Lociuro, S., Zanol, M., Colombo, L. \& 
Selva, E. (1991). Analysis of madurose and other actinomycete whole cell sugars by gas chromatography. J Microbiol Methods 14, 185-191.

Saitou, N. \& Nei, M. (1987). The neighbor-joining method: a new method for reconstructing phylogenetic trees. Mol Biol Evol 4, 406-425.

Shirling, E. B. \& Gottlieb, D. (1966). Methods for characterization of Streptomyces species. Int J Syst Bacteriol 16, 313-340.

Simon, E. W. (1953). Mechanisms of dinitrophenol toxicity. Biol Rev 28, 453-479.

Skerman, V. B. D. (1967). A Guide to the Identification of the Genera of Bacteria, 2nd edn. Baltimore: Williams \& Wilkins.

Stackebrandt, E., Rainey, F. A. \& Ward-Rainey, N. L. (1997). Proposal for a new hierarchic classification system, Actinobacteria classis nov. Int J Syst Bacteriol 47, 479-491.

Takeuchi, M. \& Hatano, K. (1998). Gordonia rhizosphera sp. nov. isolated from the mangrove rhizosphere. Int J Syst Bacteriol $\mathbf{4 8}$, 907-912.

Tamaoka, J. \& Komagata, K. (1984). Determination of DNA base composition by reverse-phase high-performance liquid chromatography. FEMS Microbiol Lett 25, 125-128.

Thompson, J. D., Higgins, D. G. \& Gibson, T. J. (1994). CLUSTAL $\mathrm{W}$ : improving the sensitivity of progressive multiple sequence alignment through sequence weighting, position-specific gap penalties and weight matrix choice. Nucleic Acids Res 22, 4673-4680.

Uchida, K. \& Aida, K. (1977). Acyl type of bacterial cell wall: its simple identification by colorimetric method. J Gen Appl Microbiol 23, 249-260.

Wayne, L. G., Brenner, D. J., Colwell, R. R. \& 9 other authors (1987). International Committee on Systematic Bacteriology. Report of the ad hoc committee on reconciliation of approaches to bacterial systematics. Int J Syst Bacteriol 37, 463-464.

Weisburg, W. G., Barns, S. M., Pelletier, D. A. \& Lane, D. J. (1991). $16 \mathrm{~S}$ ribosomal DNA amplification for phylogenetic study. $J$ Bacteriol 173, 697-703.

Williams, S.T., Goodfellow, M., Alderson, G., Wellington, E. M. H., Sneath, P. H. A. \& Sackin, M. J. (1983). Numerical classification of Streptomyces and related genera. J Gen Microbiol 129, 1743-1813.

Yoon, J.-H., Kim, H., Kim, S.-B., Kim, H.-J., Kim, W. Y., Lee, S. T., Goodfellow, M. \& Park, Y.-H. (1996). Identification of Saccharomonospora strains by the use of genomic DNA fragments and rRNA gene probes. Int J Syst Bacteriol 46, 502-505.

Yoon, J.-H., Rhee, S.-K., Lee, J.-S., Park, Y.-H. \& Lee, S. T. (1997). Nocardioides pyridinolyticus sp. nov., a pyridine-degrading bacterium isolated from the oxic zone of an oil shale column. Int $J$ Syst Bacteriol 47, 933-938.

Yoon, J.-H., Lee, S. T. \& Park, Y.-H. (1998). Inter- and intraspecific phylogenetic analysis of the genus Nocardioides and related taxa based on $16 \mathrm{~S}$ rDNA sequences. Int $J$ Syst Bacteriol 48, 187-194.

Zeyer, J. \& Kearney, P. C. (1984). Degradation of $o$-nitrophenol and $m$-nitrophenol by a Pseudomonas putida. J Agric Food Chem 32, 238-242. 